\title{
Life Cycle Assessment of Biomass Use in the Torrefaction Process
}

\author{
Maria Bałazińska* \\ Institute for Chemical Processing of Coal, 1 Zamkowa Street, 41-803, Zabrze, Poland
}

Received: 6 February 2017

Accepted: 24 May 2017

\begin{abstract}
This paper presents comparative life cycle assessment (LCA) for biomass use in the torrefaction process. The analysis took into account the climate change category for a time horizon of 100 years. It considered subsequent stages of biomass life cycle, i.e., the stage of biomass preparation for the torrefaction process, starting from its transport until its processing (thermal treatment) on torrefaction installation. Palm kernel shell (PKS) and Polish woodchips were selected as the biomass to be analyzed. The functional unit was selected to be $1 \mathrm{Mg}$ of torrefied biomass. The torrefaction process was carried out in an installation at the Institute for Chemical Processing of Coal (ICPC).

The analysis showed that among the considered life stages of PKS and woodchips, the biggest environmental load indicates the torrefaction stage. The estimated environmental effect is several orders of magnitude larger in comparison with other stages of biomass life.
\end{abstract}

Keywords: life cycle assessment, torrefaction, wood, palm kernel shell, biomass

\section{Introduction}

Replacing fossil fuel with biomass will have positive effects on the environment [1]. Energy production from biomass causes technological problems associated with different physicochemical properties between biomass and coal. These differences are related to the higher moisture content and higher combustible parts in biomass. In addition, the biomass is characterized by high content of chlorine and different ash components in relation to coal. This entails a risk to equipment of installation, which was specifically described/studied by Kopczyński and Zuwała [2]. For such systems, one of the solutions (next to changing technology) is the proper preparation of

*e-mail: mbalazinska@ichpw.pl mbalazinska@ichpw.pl biomass, i.e., by the torrefaction process. The torrefaction process is rapidly gaining popularity because it reduces the volume of the biomass along with a reduction in moisture and chlorine, which significantly improves the grinding properties [2]. Therefore, torrefied biomass recently has gained in popularity. The goal of torrefied biomass use is to reduce the negative environmental impacts to the environmental from fossil fuel combustion. An environmental impact assessment (EIA) indicator is typically used to evaluate the environmental impact of biomass use for energy purposes [3]. In this study, however, LCA analysis [1, 4-7] was used for this purpose, since it is the preferred method for the energy sector [8]. LCA involves the collection and evaluation of inputs and outputs as well as the potential environmental impacts of the product system during its life cycle.

This paper presents a comparative LCA analysis including a listing of the environmental effects for using 
palm kernel shell (PKS) and woodchips in the torrefaction process. PKS was very popular on the Polish biomass market in 2013 when the research was started, as a result of low price and high calorific value in comparison to other biomass fuels. However, woodchips are an example of Polish native biomass. Analysis was carried out using the results from biomass torrefaction tests at an installation located at the Institute for Chemical Processing of Coal (ICPC). Collected results were supplemented with missing literature data. The presented results were developed within the BioPoGen project funded by the European Institute of Innovation and Technology.

\section{Materials and Methods}

\section{Life Cycle of Biomass Use in Torrefaction Process}

According to guidelines in ISO 14040 [9] and ISO 14044 [10], the comparative LCA analysis should take into account the corresponding stages of life for the tested products, which allows for comparison of results for analyzed cases. It is necessary to define the system boundaries. The process of making these decisions is defined in detail by the LCA methodology. This analysis includes an exploitation component. Partial life cycle of torrefied biomass was evaluated (in the terminology of LCA it is called "gate-to-gate" analysis). It included the stage of biomass preparation for the torrefaction process, starting from its transport until its processing (thermal treatment) on torrefaction installation. These stages are the next unit processes that make up studied systems of PKS and woodchips (Fig. 1).

Earlier and further life cycle stages associated with cultivation, plant growth, and further use of torrefied biomass were omitted. This decision is justified by a number of arguments.

In the case of PKS, the life cycle stages associated with the plant growth in order to obtain biomass are burdened with zero emissions. This follows from the fact that oil palm is cultivated to obtain palm oil. Therefore, for palm oil as a product of the process, all emissions are assigned.

The organoleptic test showed that the woodchip biomass came from pine trees. The potential of residual

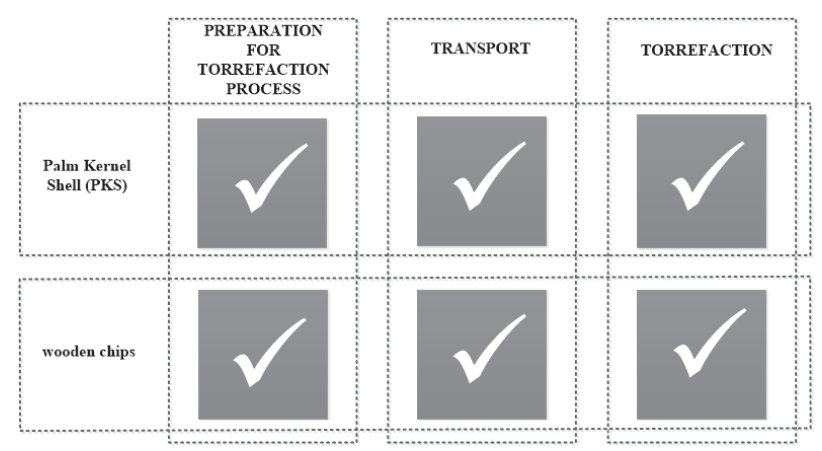

Fig. 1. Scope of LCA analysis. forest biomass is significant, which was considered in [11]. There are two ways of obtaining pine woodchips, i.e., woodchips may be obtained from deforestation, or as byproduct from sawmills. In the first case, the cut wood is evaluated by a garbler. If it is classified as full value, it is directed to a sawmill and from there to the furniture industry. On the other hand, if it is classified as defective, it is subjected to shredding and directed to energy use. The second possibility to obtain chips is to shred the wood derived from wood processing performed in sawmills. In both the first and second cases, the wood chips are recognized as wood waste. Thus, as in the case of PKS, emissions for the shredding stage (preparation) is not assigned to the wood chips.

As regards the stage of torrefied biomass use for energy production, it is possible to apply many different technological solutions that aggravate the environment to lesser or greater extents. Therefore, without knowledge about the technology and its potential application, it is problematic to determine emissions. This assumption may have led to a huge error. At the same time it must be assumed that these values would be similar for each case, meaning that the result would not affect emissions, but only impact its error. For this reason, it is not reasonable to take this into account in the analysis.

Palm seeds are collected and transported to the palm oil production plant for extraction of oil. The shredded palm kernels are considered to be a waste product. Received kernel shells have particles size ranging from 10 to $25 \mathrm{~mm}$. These values coincide with the required scope of biomass granulation to use in ICPC installation. There is no need for additional grinding material for the torrefaction process. Therefore, in the preparation of the LCA analysis it was assumed zero $\mathrm{CO}_{2}$ emissions for PKS preparation for the torrefaction process. For the purpose of analysis it was also assumed that Malaysia has the largest production potential in the world [12] and produces $4 \mathrm{mln}$ tons of PKS annually [13]. The palm oil production plant is Sri Kamusan Palm Oil Mill in Borneo. The shells are transported by truck to the container port Sabah Ports Sdn. Bhd. From there they are transported in container ships to Gdańsk, Poland, from which they are transported by truck to Zabrze. PKS are then thermally processed at the ICPC installation.

Pine woodchips are obtained from wood waste derived from a sawmill. It was assumed that the wood is shredded by a gross type gas $62 \mathrm{~S}$ shredder equipped with a $20 \mathrm{~mm}$ sieve. The sawmill is located in Orzesze, from which the chips are transported to the ICPC, where the biomass is thermally processed in the installation for biomass torrefaction.

The assumptions for biomass transportation are presented in Tables 1-2.

Calculations were made for one truck transporting biomass. For road transport it was assumed that the biomass was transported every time by the same means of transport, i.e., Scania truck R114LA4x2NA 380 with a Kogel S24 semi-trailer. This will allow us to compare the results of emissions. The European emission standard 
Table 1. Characteristics of PKS transport from Sri Kamusan Palm Oil Mill to ICPC.

\begin{tabular}{|c|c|c|c|c|}
\hline Route & Means of transportation & Fuel & \multicolumn{2}{|c|}{ Route length $(\mathrm{km})$} \\
\hline $\begin{array}{l}\text { Sri Kamusan Palm Oil Mill to Sabath Ports } \\
\text { Snd. Bhd. }\end{array}$ & $\begin{array}{l}\text { Scania R114LA4x2NA } 380 \text { with semi-trailer } \\
\text { (truck) }\end{array}$ & diesel & 217 & \multirow{3}{*}{19,065} \\
\hline Sabath Ports Snd. Bhd. to DCT Gdańsk & Container & bunker 380 & 18,321 & \\
\hline DCT Gdańsk to ICPC, Zabrze & $\begin{array}{l}\text { Scania R114LA4x2NA } 380 \text { with semi-trailer } \\
\text { (truck) }\end{array}$ & diesel & 527 & \\
\hline
\end{tabular}

Table 2. Characteristics of woodchips transported from Pasieka Sawmill to ICPC.

\begin{tabular}{|c|c|c|c|}
\hline Route & Means of transportation & Fuel & Route length $(\mathrm{km})$ \\
\hline Pasieka Sawmill, Orzesze to ICPC, Zabrze & Scania R114LA4x2NA 380 with semi-trailer (truck) & diesel & 32 \\
\hline
\end{tabular}

for the engine used in this truck is Euro 3 [14]. A load of a semi-trailer is $28.130 \mathrm{Mg}$ [15]. It should be noted that the calculation was based on average fuel consumption of the truck at a level of 33.33 liters of diesel per $100 \mathrm{~km}$ [14]. In turn, the maritime transport burns bunker 380, whose average fuel consumption is assumed to be 40 tons per day [16]. During the BioPoGen project the biomass was not dried forcibly before its feeding to the torrefaction installation, thus the drying process is not included as one of the stages of the life cycle of biomass directed to the installation.

The last stage of the life cycle of PKS and woodchips involved in analysis is the torrefaction process carried out at the ICPC biomass torrefaction installation which is in Zabrze (Fig. 2).

The main components of the installation are the combustion chamber and torrefaction reactor. During start-up the kindling fuel is directed to the combustion chamber. Hot exhaust gases and a small quantity of ash are produced during combustion. Exhaust gases are used to heat the entire plant. After heating the installation to a suitable temperature, the raw biomass to the torrefaction reactor is added. Biomass is torrefied in the countercurrent flow operation at $350^{\circ} \mathrm{C}$. The products of the process are torrefied biomass and gas, which at the beginning is steam (when the moisture from biomass evaporates) and then processing gas, or torgas - the mixture of exhaust gas and gaseous products from the torrefaction process after dusting is directed into the combustion chamber. Part of the exhaust gas from the combustion chamber is directed to the environment. When the exhaust gas reaches $700^{\circ} \mathrm{C}$, the biomass is fed into the combustion chamber and the process is carried out under autothermal conditions [1516]. LCA was conducted for steady state operation.

\section{Assumptions and Data for LCA Analysis}

The analysis was conducted for climate change for a time horizon of 100 years [19]. The climate change category includes greenhouse gases emissions during the life cycle of the analyzing product, i.e., biomass use in the torrefaction process. Subsequent stages of life cycle of torrefaction of biomass are presented in Fig. 1. For the torrefaction stage, direct emissions from torrefaction were limited to only $\mathrm{CO}_{2}$ due to difficulties in identifying other greenhouse gases released from the installation. This assumption is justified because carbon dioxide is the most responsible for climate change. In the case of other

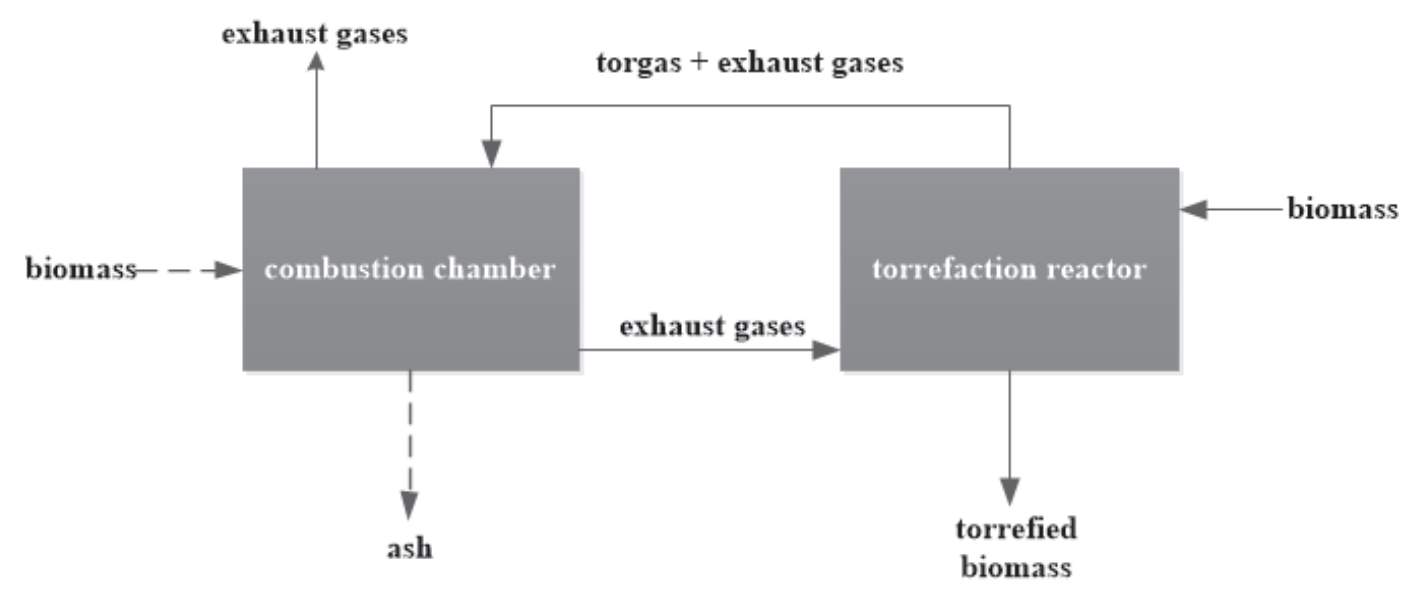

Fig. 2. ICPC biomass torrefaction installation mechanism of action (symbols: dashed lines mark periodic mass streams) [based on 17-18]. 
greenhouse gases, one can observe a smaller contribution to the increase of global temperature [20]. The boundaries of product systems are shown in Figs 3 and 4.

LCA is performed in reference to the functional unit, which determines the quantitative effect of the product. Thus, for the analyzed case it will be $1 \mathrm{Mg}$ of received torrefied PKS and woodchips. Inventoried input and output data referring to the functional unit are summarized in Tables 3 and 4.

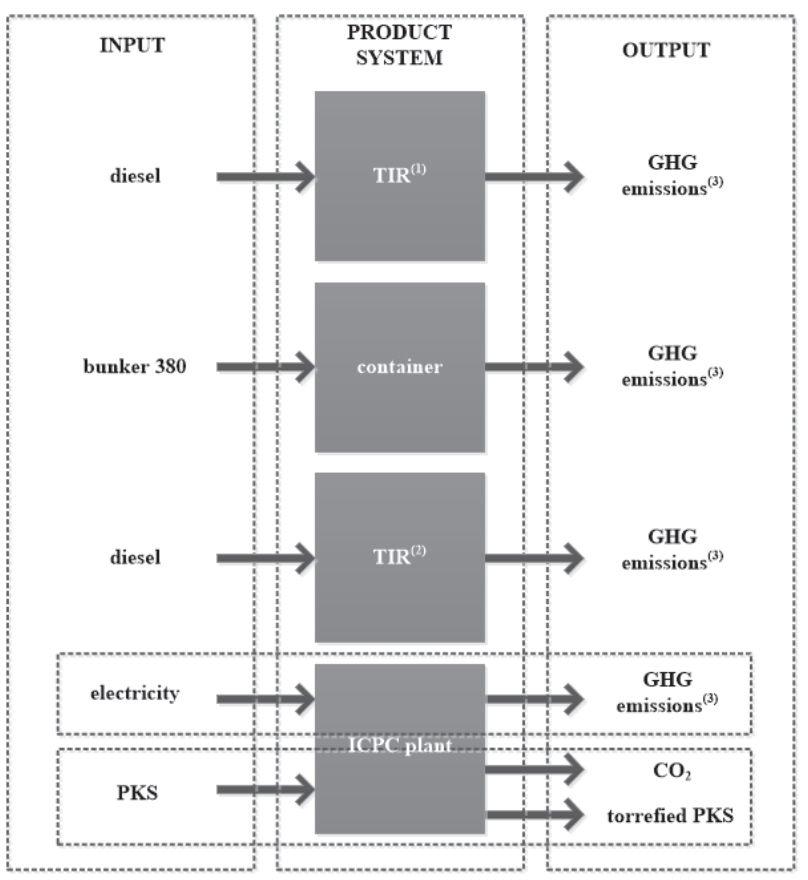

Fig. 3. Boundaries of product system for PKS.

1) Applies to route Sri Kamusan Palm Oil Mill, to Sabath Ports Snd. Bhd.

2) Applies to route DCT Gdańsk to ICPC, Zabrze.

3) GHG: greenhouse gas emissions.

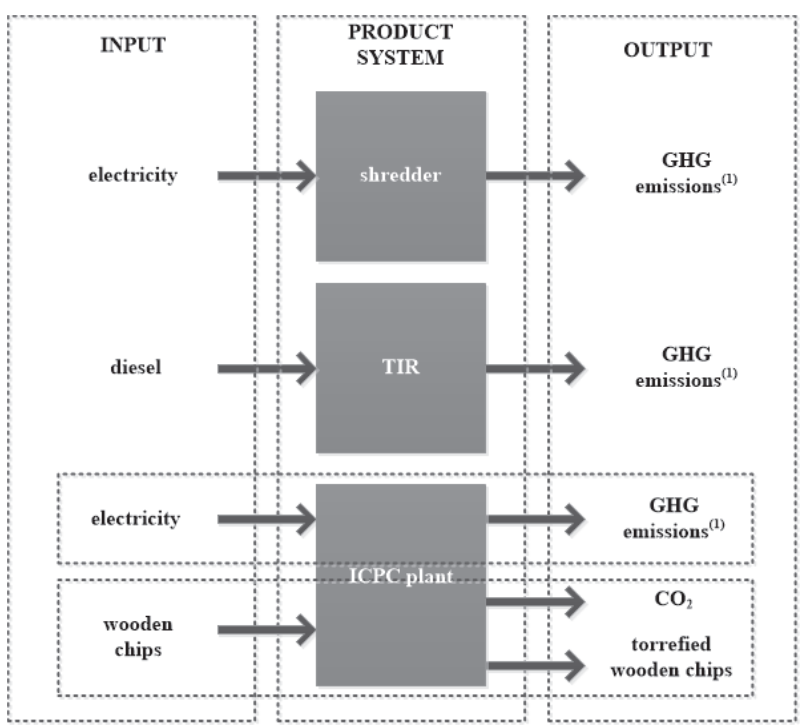

Fig. 4. Boundaries of product system for woodchips. GHG - greenhouse gas emissions.
Emissions related to maritime transport of PKS is an order of magnitude higher as regards to emissions for road transportation. However, these values are insignificant compared to the level of direct emissions resulting from operating torrefaction installation.

Within the stage of woodchip preparation for the torrefaction process we must take into account the shredding stage, which PKS does not require. Indirect emissions resulting from electricity consumption from Polish energy system for the needs of the shredder are considerable. In addition, comparing data from Tables 3 and 4, the difference in the efficiency of the process between PKS and woodchip torrefaction draws attention. To produce $1 \mathrm{Mg}$ of torrefied PKS, $4.78 \mathrm{Mg}$ of raw biomass is needed. However, in the case of woodchips the value decreases to a level of $3.92 \mathrm{Mg}$.

\section{Results}

The life cycle impact assessment includes all obligatory elements, i.e., selection of impact category, category indicators, characterization models, and classification and characterization. From optional elements we carried out a normalization step. The value of normalization indicator used in the calculation is assigned to Western Europe (1995) [21]. Tables 5 and 6 showed the results of the analysis.

Greenhouse gas emissions for the torrefaction stage are four orders of magnitude higher than for the PKS transport stage. Therefore, a small reduction of emissions generated during the torrefaction process significantly reduces the final value of emissions into the environment.

For the analyzed stages of life for chips, the lowest impact on the final greenhouse gas emissions to the environment is recorded for the transport step. The preparation process had a large impact on the environment, but the biggest impact came from the torrefaction process. Referring obtained results to emissions per equivalent inhabitant in Europe within a year, it is achieved at 3.24E$01 \mathrm{IE} \cdot$ year/ $\mathrm{Mg}_{\text {torrefied_biomass }}$ total emissions for PKS, and 2.80E-01 IE-year/ $\mathrm{Mg}_{\text {torrefied biomass }}$ for woodchips.

\section{Discussion}

Literature studies were carried out for LCA analysis for biomass used in the torrefaction process. They were conducted to compare results for torrefied biomass produced in other technologies than those proposed in the BioPoGen project. To compare LCA results between themselves, corresponding life stages, system boundaries, and functional units are necessary. Only one publication has fulfilled these conditions.

[22] presents LCA analysis for different scenarios related to the production of torrefied olive husk. For each of two options (i.e., biomass extraction in its processing location and transport within $100 \mathrm{~km}$ ), four scenarios relating to energy delivery to the torrefaction 
Table 3. Inventoried data necessary to carry out LCA for torrefied PKS.

\begin{tabular}{|c|c|c|c|c|c|c|c|}
\hline \multirow{2}{*}{$\begin{array}{c}\text { Considered stages } \\
\text { of biomass life } \\
\text { cycle }\end{array}$} & \multirow{2}{*}{$\begin{array}{l}\text { Unit } \\
\text { process }\end{array}$} & \multicolumn{3}{|c|}{ Input } & \multicolumn{3}{|c|}{ Output } \\
\hline & & Flux & Unit & Value & Flux & Unit & Value \\
\hline $\begin{array}{l}\text { Preparation for } \\
\text { torrefaction process }\end{array}$ & - & - & - & - & - & - & - \\
\hline \multirow{3}{*}{ Transport } & truck* & diesel & $1 / \mathrm{Mg}_{\text {torrefied biomass }}$ & $1.23 \mathrm{E}+01$ & GHG emission & $\begin{array}{c}\mathrm{MgCO}_{2 \mathrm{eq}} / \mathrm{Mg}_{\text {torrefied }} \\
\text { biomass }\end{array}$ & $3.82 \mathrm{E}-05$ \\
\hline & container & bunker 380 & $\mathrm{Mg} / \mathrm{Mg}_{\text {torrefied biomass }}$ & $3.43 \mathrm{E}-02$ & GHG emission & $\mathrm{MgCO}_{2 \mathrm{eq}} / \mathrm{Mg}_{\text {torrefied }}$ & $1.17 \mathrm{E}-04$ \\
\hline & truck** & diesel & $1 / \mathrm{Mg}_{\text {torrefied biomass }}$ & $2.99 \mathrm{E}+01$ & GHG emission & $\begin{array}{c}\mathrm{MgCO}_{2} \mathrm{eq} / \\
\mathrm{Mg}_{\text {torrefied biomass }}\end{array}$ & $9.28 \mathrm{E}-05$ \\
\hline \multirow{3}{*}{ Torrefaction } & \multirow{3}{*}{$\begin{array}{l}\text { ICPC } \\
\text { plant }\end{array}$} & electricity & $\mathrm{kWh} / \mathrm{Mg}_{\text {torrefied biomass }}$ & $9.23 \mathrm{E}+01$ & GHG emission & $\begin{array}{c}\mathrm{MgCO}_{2} \mathrm{eq} / \\
\mathrm{Mg}_{\text {torrefeied biomass }} \\
\end{array}$ & $1.07 \mathrm{E}-01$ \\
\hline & & \multirow[t]{2}{*}{ PKS } & \multirow{2}{*}{$\begin{array}{c}\mathrm{Mg}_{\mathrm{PKS}} / \\
\mathrm{Mg}_{\text {torrefied biomass }}\end{array}$} & \multirow[t]{2}{*}{$4.78 \mathrm{E}+00$} & $\mathrm{CO}_{2}$ emission & $\begin{array}{c}\mathrm{MgCO}_{2} / \mathrm{Mg}_{\text {torrefied }} \\
\text { biomass }\end{array}$ & $4.62 \mathrm{E}+00$ \\
\hline & & & & & Torrefied PKS & $\mathrm{Mg}_{\text {torrefied biomass }}$ & $1.00 \mathrm{E}+00$ \\
\hline
\end{tabular}

*Applies to transportation on route Sri Kamusan Palm Oil Mill to Sabath Ports Snd. Bhd.

**Applies to transportation on route DCT Gdańsk to IChPW, Zabrze

Table 4. Inventoried data necessary to carry out LCA for torrefied woodchips referring to functional unit.

\begin{tabular}{|c|c|c|c|c|c|c|c|}
\hline \multirow{2}{*}{$\begin{array}{c}\text { Considered stages } \\
\text { of biomass life } \\
\text { cycle }\end{array}$} & \multirow{2}{*}{$\begin{array}{c}\text { Unit } \\
\text { process }\end{array}$} & \multicolumn{2}{|c|}{ Flux } & Unit & Value & Flux & \multicolumn{2}{|c|}{ Unit } & Value \\
\cline { 6 - 9 } $\begin{array}{c}\text { Preparation for } \\
\text { torrefaction } \\
\text { process }\end{array}$ & shredder & electricity & $\begin{array}{c}\mathrm{kWh} / \mathrm{Mg}_{\text {torrefied }} \\
\text { biomass }\end{array}$ & $1.81 \mathrm{E}+02$ & $\begin{array}{c}\mathrm{GHG} \\
\text { emission }\end{array}$ & $\mathrm{MgCO}_{2 \mathrm{eq}} / \mathrm{Mg}_{\text {torrefied }}$ & $2.10 \mathrm{E}-01$ \\
\hline biomass
\end{tabular}

Table 5. Results of LCA for torrefied PKS.

\begin{tabular}{|c|c|c|c|c|c|}
\hline \multirow{2}{*}{ LCIA step } & \multirow{2}{*}{ Unit } & \multicolumn{2}{|c|}{ Considered "life" stages of biomass } & \multirow{2}{*}{ Sum } \\
\cline { 3 - 5 } & & Preparation for torrefaction process & Transport & Torrefaction & \\
\hline Characterization & $\mathrm{MgCO}_{2 \mathrm{eq}} / \mathrm{Mg}_{\text {torrefied_biomass }}$ & - & $2.49 \mathrm{E}-04$ & $4.73 \mathrm{E}+00$ & $4.73 \mathrm{E}+00$ \\
\hline Normalization & $\mathrm{IE}^{*} \cdot \mathrm{year} / \mathrm{Mg}_{\text {torrefie__biomass }}$ & - & $1.70 \mathrm{E}-05$ & $3.24 \mathrm{E}-01$ & $3.24 \mathrm{E}-01$ \\
\hline
\end{tabular}

*Inhabitant equivalent (IE)

Table 6. The results of LCA for torrefied woodchips.

\begin{tabular}{|c|c|c|c|c|c|}
\hline \multirow{2}{*}{ LCIA step } & \multirow{2}{*}{ Unit } & \multicolumn{2}{|c|}{ Considered "life" stages of biomass } & \multirow{2}{*}{ Sum } \\
\cline { 3 - 5 } & & Preparation for torrefaction process & Transport & Torrefaction & \\
\hline Characterization & $\mathrm{MgCO}_{2 \mathrm{eq}} / \mathrm{Mg}_{\text {torrefied_biomass }}$ & $2.10 \mathrm{E}-01$ & $4.62 \mathrm{E}-06$ & $3.87 \mathrm{E}+00$ & $4.08 \mathrm{E}+00$ \\
\hline Normalization & $\mathrm{IE}^{*} \cdot \mathrm{year} / \mathrm{Mg}_{\text {torrefied_biomass }}$ & $1.44 \mathrm{E}-02$ & $3.16 \mathrm{E}-07$ & $2.65 \mathrm{E}-01$ & $2.80 \mathrm{E}-01$ \\
\hline
\end{tabular}

*Inhabitant equivalent (IE) 
Table 7. Results of LCA for torrefied biomass.

\begin{tabular}{|c|c|c|c|c|c|c|c|c|c|c|}
\hline & \multicolumn{7}{|c|}{$\begin{array}{c}\text { BioPoGen project - } \\
\text { IChPW technology }\end{array}$} & \multicolumn{8}{|c|}{ Scenarios presented in [22]* } \\
\cline { 2 - 10 } & PKS & Woodchips & Ia & Ib & Ic & Id & IIa & IIb & IIc & IId \\
\hline $\begin{array}{c}\text { Climate change, } \\
\mathrm{MgCO}_{\text {2eq }} / \mathrm{Mg}_{\text {torrefied }} \\
\text { biomass }\end{array}$ & $4.73 \mathrm{E}+00$ & $4.08 \mathrm{E}+00$ & $\begin{array}{c}7.22 \mathrm{E}- \\
02\end{array}$ & $\begin{array}{c}8.88 \mathrm{E}- \\
02\end{array}$ & $\begin{array}{c}3.95 \mathrm{E}- \\
02\end{array}$ & $\begin{array}{c}3.44 \mathrm{E}- \\
02\end{array}$ & $\begin{array}{c}1.02 \mathrm{E}- \\
01\end{array}$ & $\begin{array}{c}1.18 \mathrm{E}- \\
01\end{array}$ & $\begin{array}{c}7.31 \mathrm{E}- \\
02\end{array}$ & $\begin{array}{c}6.17 \mathrm{E}- \\
02\end{array}$ \\
\hline
\end{tabular}

* I - place of biomass extraction is also the place where it is processing, II - place of biomass extraction is $100 \mathrm{~km}$ away from the processing location; heat for drying and for torrefaction process comes from combustion of: a) diesel oil, b) natural gas, c) pellets from wood, and d) heat obtained from solar collectors.

process were considered. Each time, torgas derived from the torrefaction process is one of the system products. Another scenario includes fuel combustion to recover the heat from exhaust gas, which covers the demand for heat for biomass drying and the torrefaction process. One ton of torrefied biomass was selected as the functional unit for comparison. Analysis was performed using the CML method. The largest emissions are observed for energy use of diesel oil, and a little less for natural gas. The lowest emissions are for the energy produced from solar panels. The presented analysis, as performed in the BioPoGen project, are characterized by mass of torrefied biomass produced as a functional unit. System boundaries also have been led similarly, i.e., from extraction place of biomass to produced torrefied biomass. Therefore, the results can be compared to those presented in [22] (Table 7).

Greenhouse gas emissions presented in [22] are one-totwo orders to magnitude lower than those obtained for the ICPC technology. It should be noted that the technological systems for these two cases are completely different. In ICPC technology the system operates under autothermal conditions. There is no need to use any other fuel for the process than biomass that will be processed. However, in [22] there is a separate system with a boiler and heat exchanger that provides heat to the torrefaction process. This solution is very expensive. It forces the additional investment costs for investors that do not exist in the case of the technology provided by ICPC. It should also be noted that the terms of analysis presented in [22] are only theoretical, because they come from appropriate computer simulations. These results had been not validated on results from experimental work carried out on installation under real conditions.

\section{Conclusions}

This paper presents LCA analysis for biomass use in the torrefaction process in ICPC technology, which was developed within the BioPoGen project. Biomass life cycle stages of preparation, transportation, and the torrefaction process were considered for two cases: palm kernel shells and woodchips. The functional unit of comparison was selected as $1 \mathrm{Mg}$ of torrefied biomass.

The results indicate that the transport stage had the smallest environmental impact and a higher emission level was noted for the preparation stage. The torrefaction process stage had the largest environmental impact, with emissions of $4.73 \mathrm{MgCO}_{2}$ eq per $\mathrm{kg}$ of torrefied PKS and $3.87 \mathrm{MgCO}_{2}$ eq per $\mathrm{kg}$ of woodchips. Overall emissions for $1 \mathrm{Mg}$ of torrefied biomass were $4.73 \mathrm{MgCO}_{2}$ eq for PKS and $4.08 \mathrm{MgCO}_{2}$ eq for woodchips. This shows the degree of impact of the torrefaction process stage on overall greenhouse gas emissions.

In [22] the biomass torrefaction technology is significantly different than the technology developed by ICPC. In those technologies, the heat for the process is derived from external sources, not from processing biomass, which is subjected to torrefaction. Furthermore, the analysis presented in [22] includes only theoretical results, which have not been validated with experimental results obtained under actual operating conditions. Thus the lower emissions are justified in comparison to those obtained for ICPC technology.

\section{Acknowledgements}

This research was done under the project "Biocoal for Power Generation" (BIOPOGEN) funded by the European Institute of Innovation and Technology (EIT).

\section{References}

1. SPATH P.L., MANN M.K. Coal versus biomass electricity generation - comparing environmental implications using life cycle assessment, National Renewable Energy Laboratory, 1997.

2. KOPCZYŃSKI M., ZUWAŁA J. Biomass torrefaction as a way for elimination of technical barriers existing in largescale co-combustion, Energy Policy Journal, 16 (4), 271, 2013 [In Polish].

3. MAJ G. Diversifiaction and Environmental Impact Assessment of Plant Biomass Energy Use, Pol. J. Environ. Stud., 24 (5), 2055, 2015.

4. PERILHON C., ALKADEE D., DESCOMBES G., LACOUR S. Life Cycle Assessment Applied to Electricity Generation from Renewable Biomass, Energy Procedia, 18, $165,2012$.

5. VASQUEREZ SANDOVAL M.A., Life Cycle Assessment of Biomass for Generation of energy: Case Studies of Poplar Management in the Pacific Northwest of the U.S.A., A disseration. Submitted to Oregon State University, 2015. 
6. FRANÇOIS J., FORTIN M., PATISSON F., MAUVIEL G., FEIDT M., ROGAUME C., ROGAUME Y., MIRGAUX O., DUFOUR A. LCA from Biomass Powerplants: from Soil to Electricity, $3^{\text {rd }}$ International Exergy, Life Cycle Assessment, and Sustainability Workshop \& Symposium (ELCAS3) Nisyros, Greece, 2013.

7. GOGLIO P., OWENDE P.M.O., A screening LCA of short rotation coppice willow (Salix $s p$.) feedstock production system for small-scale electricity generation. Biosyst. Eng. 103, 389, 2009.

8. DZIKUĆ M., PIWOWAR A. Life Cycle Assessment as an Eco-Management Tool within the Power Industry, Pol. J. Environ. Stud., 24 (5), 2381, 2015.

9. ISO 14040 Environmental management - Life cycle assessment - Principles and framework, International Organization for Standardization, 2006.

10. ISO 14044 Environmental management - Life Cycle Assessment - Requirements and guidelines, International Organization for Standardization, 2006.

11. WOCH F., HERNIK J., WYROZUMSKA P., CZESAK B., Residual Woody Waste Biomass as an Energy Source - Case Study, Pol. J. Environ. Stud., 24 (1), 355, 2015.

12. ABDULLAH I., WAN MAHMOOD W. H., MD FAUADI M. H. F., AB RAHMAN M. N., AHMAD F., Sustainability in Malaysian Palm Oil: A Review on Manufacturing Perspective, Pol. J. Environ. Stud., 24 (4), 1463, 2015.

13. ITAM Z. BEDDU S., LIYANA MOHD KAMAL N., ASHRAFUL ALAM MD., ISSA AYASH U., The Feasibility of Palm Kernel Shell as a Replacement for Coarse Aggregate in Lightweight Concrete, IOP Conference Series: Earth and Environmental Science, 32 (1), $012040,2016$.
14. www.truck.pl (accessed on 20.05.2015)

15. Catalogue Chogi company https://chogi.pl/ (accessed on 20.03.2016)

16. http://www.seaplus.com (accessed on 15.04.2016)

17. ZUWAŁA J., CZARDYBON A., KOPCZYŃSKI M., Biomasa toryfikowana - kierunek energetyka, ale i...rolnictwo. http://magazynbiomasa.pl/biomasa-toryfikowana-kierunekenergetyka-rolnictwo/ (accessed on 25.08.2016)

18. SAJDAK M., CHRUBASIK M., MUZYKA R., Chemical characterisation of tars from the thermal conversion of biomass by $1 \mathrm{D}$ and $2 \mathrm{D}$ gas chromatography combined with silylation, J. Anal. Appl. Pyrol., 124, 426, 2017.

19. Intergovernmental Panel on Climate Change, www.ipcc.ch (accessed on 20.08.2016).

20. Why does $\mathrm{CO} 2$ get most of the attention when there are so many other heat-trapping gases (greenhouse gases)?, Union of Concerned Scientists, www.ucsusa.org (accessed on 22.05.2016)

21. GUINÉE J.B. (ED.), GORRÉE M., HEIJUNGS R., HUPPES G., KLEIJN R., DE KONING A., VAN OERS L., WEGENER SLEESWIJK A., SUH S., UDO DE HAES H.A., DE BRUIJN H., VAN DUIN R., HUIJBREGTS M.A.J., Handbook on Life Cycle Assessment - Operational Guide to the ISO Standards, 1st ed.; Springer Netherlands, Netherlands, 269, 2001.

22. CHRISTOFOROU E.A., FOKAIDES P.A., Life cycle assessment (LCA) of olive husk torrefaction, Renewable Energy 90, 257, 2016. 